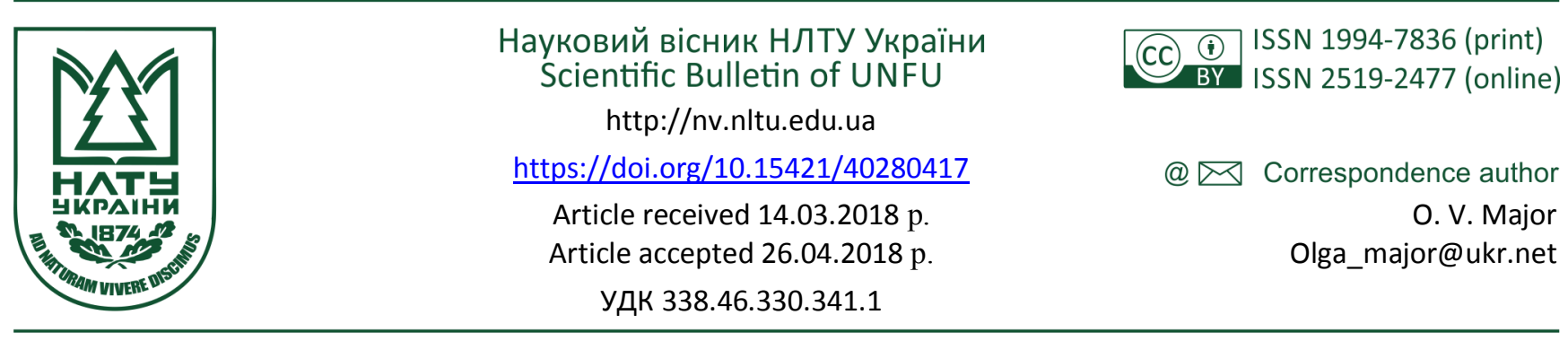

О. В. Майор, Н. А. Свелеба

Львівський інститут економіки і туризму, м. Львів, Украӥна

\title{
ДЕЯКІ ОСОБЛИВОСТІ ФОРМУВАННЯ ФІНАНСОВО-КРЕДИТНИХ ІНСТРУМЕНТІВ ІННОВАЦІЙНОГО РОЗВИТКУ ПІДПРИЄМСТВ СФЕРИ ПОСЛУГ
}

Розглянуто проблеми формування в сучасних умовах інструментів інноваційного розвитку підприємств сфери послуг. Досліджено підприємства сфери послуг (торгівля, готелі, підприємства харчування, туристичні фірми). Визначено основні джерела фінансування інноваційного розвитку підприємств сфери послуг. Встановлено, що фінансове забезпечення інноваційного розвитку малих підприємницьких структур здійснюють переважно за рахунок власних джерел. Визначено роль $\mathrm{i}$ значення фінансово-кредитних інструментів для інноваційного розвитку сфери послуг. Визначено роль і місце банківського кредитування у фінансуванні інноваційного розвитку підприємств сфери послуг. З'ясовано місце та значення використання лізингу як інструменту забезпечення інноваційного розвитку малих підприємницьких структур. Розглянуто роль франчайзингу та факторингу в забезпеченні інноваційного розвитку підприємницьких структур. Запропоновано створення ефективної франчайзингової мережі як засобу фінансування інноваційної діяльності малих підприємницьких структур. Рекомендовано українським підприємницьким структурам у системі фінансового забезпеченням бізнесової діяльності використовувати форфейтинг. Визначено, що перспективним для фінансування інноваційного розвитку підприємств сфери послуг $є$ залучення кредитних спілок та страхових компаній. Запропоновано реформувати структуру банківського сектора 3 метою створення банків другого рівня, які б здійснювали кредитування на пільгових умовах. Запропоновані рекомендації є базовими у формуванні фінансово-кредитного механізму інноваційного розвитку підприємств сфери послуг.

Ключові слова: самофінансування; інвестиції; кредит; акціонування; лізинг; франчайзинг; кредитні спілки.

Вступ. В умовах розвитку сучасного суспільства, одним із основних напрямів економічного зростання підприємств сфери послуг є їх інноваційний розвиток, що передбачає використання принципово нових прогресивних технологій та розроблення механізмів реалізації управлінських рішень в інноваційній діяльності.

Сучасні економічні умови потребують інтенсивної інноваційної діяльності, ефективної організації досліджень та розробок, нововведень, зниження інноваційних ризиків, стратегічного управління в інноваційній діяльності підприємств сфери послуг. Тому, щоб не втратити своїх позицій на ринку та здійснювати ефективну інноваційну діяльність, підприємницькі структури сфери послуг змушені шукати нові джерела й форми інвестування та систему заходів щодо його фінансово-кредитної підтримки.

Аналіз останніх досліджень і публікацій. Проблемі формування фінансово-кредитних інструментів інноваційного розвитку підприємств сфер послуг приділили багато уваги вітчизняні вчені. Особливого значення набувають дослідження теоретичних і методологічних проблем розвитку сфери послуг. Значний внесок у дослідження зазначеної проблеми зробили такі вчені, як: О. М. Колодзієв, О. Г. Возняк, М. А. Дмитренко, Я. Б. Дропа та ін.

У наведених вище працях авторів досліджено мето- дологічні, теоретичні та практичні аспекти формування фінансово-кредитного механізму інноваційного розвитку сфери послуг. Однак недостатньо приділено уваги розробленню стратегії інноваційного розвитку з використанням фінансово-кредитних інструментів.

Формулювання цілей роботи. Незважаючи на військові дії на сході України та інші дестабілізаційні фактори, спостерігається деяке пожвавлення економічної діяльності в усіх галузях національного господарства. 3 огляду на це поступово збільшується обсяг наданих послуг населенню, а отже, ця тенденція приводить до сприятливих змін у структурі сфери послуг. Очікувані позитивні зміни висувають на перший план потреба формування стратегії інноваційного розвитку підприємств сфери послуг. Практична реалізація механізму інноваційного розвитку підприємств сфери послуг передбачає насамперед формування достатніх фінансових джерел із використанням фінансово-кредитного інструментарію.

Метою роботи $є$ розроблення рекомендацій щодо формування та використання наявного фінансово-кредитного інструментарію для забезпечення інноваційного розвитку підприємств сфери послуг.

Опис основного матеріалу дослідження. Під фінансовим забезпеченням інноваційного розвитку О. М. Колодізєв пропонує розуміти сукупність економічних

Інформація про авторів:

Майор Ольга Володимирівна, канд. екон. наук, доцент, кафедра обліку і фінансів. Email: Olga_major@ukr.net

Свелеба Наталія Андріївна, канд. екон. наук, доцент, кафедра обліку і фінансів. Email: Olga_major@ukr.net

Цитування за ДСту: Майор О. В., Свелеба Н. А. Деякі особливості формування фінансово-кредитних інструментів інноваційного розвитку підприємств сфери послуг. Науковий вісник НЛтУ України. Серія Економічна. 2018, т. 28, № 4. С. 92-96

Citation APA: Major, O. V., \& Sveleba, N. A. (2018). Some Features of Formation of Financial and Credit Instruments of Innovative Development of Service Sector Enterprises. Scientific Bulletin of UNFU, 28(4), 92-96. https://doi.org/10.15421/40280417 
відносин, що виникають з приводу пошуку, залучення i ефективного використання фінансових ресурсів, а також організаційно-управлінських принципів, методів і форм впливу цих ресурсів на інноваційний розвиток національної економіки (Kolodiziev, 2011). Найпоширенішим $\epsilon$ визначення фінансового забезпечення інноваційної діяльності як комплексу методів та інструментів впливу на інноваційну діяльність, що реалізується в різних формах через відповідну систему фінансування (Vozniak \& Kuznietsova, 2007, p. 22). Фінансове забезпечення інноваційної діяльності передбачає реалізацію заходів із залучення необхідного обсягу фінансових ресурсів для фінансування нововведень підприємства. Основним завданням фінансового забезпечення $\epsilon$ прийняття рішень щодо визначення джерел фінансування інноваційної діяльності, формування необхідних їх обсягів та оптимізації.

Сьогодні фінансове забезпечення інноваційного розвитку малих підприємницьких структур сфери послуг здійснюють за власні джерела фінансових ресурсів (самофінансування); за кошти місцевих бюджетів; кредитів банків (меншою мірою через високі процентні ставки); за кошти вітчизняних й іноземних інвесторів (їхня частка в загальному обсязі фінансування вкрай низька) та інших джерел. За розмірами підприємства сфери послуг належать до малих та середніх підприємницьких структур. Малі підприємства здійснюють капітальні вкладення переважно на основі самофінансування, що звужує їхні можливості розширеного відтворення (Dropa \& Danylkiv, 2011, p. 163). Самофінансування малі підприємницькі структури здійснюють за допомогою власних коштів у частині чистого прибутку та амортизаційних відрахувань. Значущість цих практично безальтернативних грошових каналів ще більше підсилюється тим, що внаслідок особливої чутливості до впливу деструктивних макроекономічних факторів (низький сукупний попит, інфляція, падіння сукупного виробництва і т. ін.) та коливань ринкової кон'юнктури малі суб'єкти господарювання змушені частіше змінювати технології та напрями діяльності, здійснювати ротацію, модернізацію та нарощування обладнання, щоб вижити у конкурентному протистоянні з великим та середнім виробництвом. Ці вимоги належать і до сфери послуг.

Саме так, через дефіцит власних коштів, що є основним джерелом фінансування інновацій, інноваційна політика малих підприємницьких структур сфери послуг має короткотерміновий характер і не дає змоги забезпечити умови для подальшого розвитку.

Одним із найпоширеніших способів підтримки інноваційної діяльності малих підприємницьких структур сфер послуг є банківське кредитування. Кредити комерційних банків є вагомим фінансовим інструментом стимулювання та забезпечення інноваційної діяльності, оскільки потреба повернення позики в установлений термін вимушує позичальника прискорювати інноваційний процес. Проте, на жаль, кредитами підприємства користуються не часто, і цьому є причини: достатньо високий рівень процентних ставок за банківськими кредитами, переважно поточний і короткотерміновий характер банківських пасивів, великий кредитний ризик, ризик зміни процентних ставок, низька ліквідність об'єктів застави.
Сучасні умови диктують банківським установам те, що вони повинні бути головними центрами фінансування інновацій, видавати кредити на випуск нової продукції, товарів, робіт і освоєння нової технології, розробку нової техніки. Банки не просто мають видавати довготермінову позику, а самі повинні рекомендувати нововведення на основі альтернативних проектів і бізнес-планів, на які доцільно брати кредит, виступати як пайовики 3 подальшою участю у прибутках (Kychuk, 2009, p. 22). Окрім цього, варто зазначити, що банки перевіряють витрати за інноваційним проектом, терміни його здійснення, а також контролюють строки погашення кредиту, стаючи при цьому рівноправним партнером підприємницьких структур. Завдяки цьому створюється конкурентна база фінансування: банк вибирає найефективніші, 3 найменшим ризиком для кредитування інноваційні проекти й організації, а підприємницькі структури - банк, що пропонує вигідніші умови видачі кредитів.

Альтернатива кредитуванню може бути акціонування. Акціонування, як вид залучення грошових коштів, має на увазі передачу (продаж) деякої частини власності іншій особі. При цьому грошові кошти, одержані підприємством, залишаються в його активі, оскільки їх повернення не передбачено, але в рамках договору акціонування обмовляється вид повернення позикових засобів. Це може бути або виплата грошового еквівалента дивідендів інвесторам, або інвестори самі можуть реалізувати свою частку власності в майні підприємства. Зазвичай це акції, які можна продати іншому інвестору або назад підприємству - кредитодержателю. Підприємцям, що зважились на такий вид отримання грошових коштів, варто пам'ятати, що пайове фінансування передбачає участь інвестора в менеджменті підприємства.

Достатньо поширеним методом та потужним імпульсом активізації інноваційної підприємницької діяльності, а також системи фінансування реального сектору економіки, можна вважати лізинг, оскільки саме 3 ним пов'язують певні надії на вирішення проблем браку коштів для оновлення матеріально-технічної бази та структурної перебудови економіки загалом (Danylkiv, 2012 , p. 226). Активізація лізингових послуг є досить значним інструментом для інноваційного розвитку малого підприємницького бізнесу, адже це достатньо ефективний спосіб залучення додаткових коштів; чудова альтернатива банківському кредитуванню, оскільки умови лізингу досить прозорі та зумовлені відсутністю прихованих платежів; $є$ однією 3 найцікавіших форм інвестування, що здатні значно пожвавити процес відтворення виробництва; надає потужний поштовх процесам приватизації, оновлення технологічного парку наявних підприємницьких структур і на вигідних умовах дає змогу отримувати найсучасніше вітчизняне та закордонне обладнання (Danylkiv, 2012, p. 226). Поширення лізингових відносин зменшує напруження, пов'язане з виключно банківським фінансуванням, стимулює торгівлю найновішими капітальними благами й технологіями.

Останнім часом у періодичних виданнях з'явилася низка публікацій, які популяризують франчайзинг як ефективний засіб фінансування інноваційної діяльності малих підприємницьких структур, зокрема, сфери пос- 
луг. У цих роботах франчайзинг виступає як високоефективний тандем малого і великого бізнесу, один із найефективніших способів розвитку бізнесу для фірм, що вже досягли успіху і бажають розвиватись далі, та найкраща можливість організувати надійну власну справу для дрібного підприємця, одна з найбільш ефективних форм інтеграції малих господарських структур та корпорацій (Varnalii, 2002). Для бізнесмена-початківця найцінніший і найкорисніший привілей - це можливість використати вже відпрацьовані технології й обладнання, що виправдали себе, послуги з постачання, рекламні матеріали, відому та популярну торговельну марку, отримувати постійно методичну, технологічну та інформаційну підтримку й можливість навчатися i одержувати консультації в процесі бізнесової діяльності. Такі можливості надають зазвичай великі корпорації, які уже мають досвід ведення бізнесу, знання, є власниками ноу-хау й здобули визнання у світі бізнесу та у споживачів. Саме франчайзинг, як найефективніша схема ведення бізнесу, створює сприятливі й необхідні економічні передумови для малих підприємницьких структур, даючи змогу скористатись усіма можливостями великих корпорацій.

Налагодження співпраці з успішним франчайзером допомагає малим суб'єктам господарювання у сфері послуг вирішити властиві їм проблеми. Зокрема, можливість стати самостійним підприємцем з мінімальними початковими капітальними вливаннями за всебічної підтримки досвідченого франчайзера та низькою вірогідністю банкрутства порівняно з іншими дрібними підприємствами. Така підтримка може набувати форми відкритого доступу до кредитних ресурсів як товарних, так і грошових, можливість за помірну плату використовувати результати широкомасштабних рекламних заходів, наукових розробок і маркетингових досліджень, які провів франчайзер.

Значною $є$ роль франчайзингових відносин й у вирішенні властивої українським малим підприємницьким структурам проблеми посиленої конкуренції на ринку. Використання випробуваних на практиці й позитивно зарекомендованих технологій франчайзера дає змогу підприємству франчайзі виготовляти конкурентоспроможну продукцію. Передача франчайзером спеціальних знань за допомогою навчання та професійних консультацій з управління підприємством відкриває шляхи для створення торговельних точок, успішно конкуруючих 3 іншими підприємствами, що функціонують на тому самому ринку. А набуття за короткий термін необхідних спеціалізованих знань, навчаючись за перевіреною часом ефективною програмою франчайзера й отримуючи навички роботи відповідно до стандартів високої якості, дає змогу уникнути труднощів 3 підбором надійних ділових партнерів.

Доцільно рекомендувати українським підприємницьким структурам сфери послуг у системі фінансового забезпечення фінансово-господарської діяльності використовувати форфейтинг. Ця форма фінансування інновацій здатна значно пожвавити інноваційний розвиток малих підприємств. Форфейтинг є фінансовою операцією, яка перетворює комерційний кредит на банківський за допомогою купівлі боргу в кредитора. Інвестор за браку коштів для вкладення в інновації виписує векселі й одержує відстрочення платежу, а також гарантії банку щодо забезпечення платежів. Отже, банк, який здійснює форфейтингові операції, проводить фінансування інноваційної діяльності, а в покупця з'являється можливість кредитування всього інноваційного проекту.

Актуальним стає дослідження такого фінансового інструмента, як факторинг - здатного подолати зазначені вище труднощі, при цьому він найбільше підходить для сучасних процесів розвитку малого бізнесу. Основне завдання факторингу - організувати взаємовідносини постачальника 3 покупцями так, щоб постачальник зміг надавати вагомі відтермінування платежу, не відчуваючи дефіциту оборотних коштів. Факторинг можуть використовувати малі підприємства як потужний інструмент для підтримки конкурентоспроможної позиції на ринку. 3 його допомогою малі підприємницькі структури можуть збільшити обсяг продажів, кількість покупців і конкурентоспроможність, надавши покупцям відтермінування.

Окрім цього, варто зазначити, що у розвинених країнах страхові компанії та пенсійні фонди $є$ активними учасниками в розвитку інноваційної спрямованості малого підприємництва. Ці фінансові посередники $\epsilon$ суб'єктами фінансово-кредитної системи, які забезпечують акумулювання заощаджень індивідуальних інвесторів та переливання коштів від кредиторів до позичальників.

В Україні функція страхових компаній та недержавних пенсійних фондів, як фінансового джерела інновацій у мале підприємництво, залишається нереалізованою. Отже, держава повинна створити реальні можливості для надання інституційними інвесторами коштів для здійснення інноваційних проектів, особливо представниками малого підприємництва. Особливо актуальним $\epsilon$ завдання висвітлити й обгрунтувати потенційні можливості кредитних спілок як ефективного ринкового механізму альтернативного фінансування інноваційної діяльності суб'єктів малого підприємництва, що дає змогу максимально наблизити фінансові послуги до споживачів, створити належні умови для довготермінового кредитування із застосуванням сучасної ринкової інфраструктури й фінансових інструментів (Danylkiv, 2013, p. 67-68).

До переваг таких спілок перед іншими фінансовими установами позабанківської системи треба віднести максимальну наближеність їх до безпосередніх отримувачів послуг, а також можливість позичальника за спрощеною схемою отримати кредит навіть у незначних розмірах. Кредитні спілки також мають змогу зваженіше відбирати членів спілок, а отже, і своїх клієнтів, тому під час видачі кредиту можна не так ретельно перевіряти кредитоспроможність позичальника. Окрім цього, варто наголосити, що існують сфери, в яких кредитні спілки можуть демонструвати адекватні результати діяльності і на рівних конкурувати з банківськими установами (Danylkiv, 2013, p. 68). По-перше, мікрокредитування і кредитування малого підприємництва не буде приносити банку таких доходів, як кредитування корпоративних клієнтів. Для компенсації видатків і ризиків під час видачі дрібних кредитів банки використовують підвищені відсоткові ставки і жорсткіші умови забезпечення виконання зобов'язань, що істотно знижує привабливість таких кредитів для позичальників. Тому цю нішу можуть використати саме кредитні спілки. По- 
друге, фінансово-економічна криза призвела до відтоку грошових коштів 3 депозитних рахунків комерційних банків. Це стосується не тільки тих установ, які мали проблеми у своїй діяльності, а й достатньо стійких. Така ситуація призвела до накопичення грошей на руках фізичних осіб. Тримати великі суми в умовах постійного зростання індексу цін недоречно. Тому їх повернення буде відбуватись у ті фінансові установи, які поєднають високу надійність із прийнятною дохідністю (Danylkiv, 2013, p. 68; 116).

Враховуючи той факт, що довіра певної частини населення до банківської системи дещо похитнулась, у кредитних спілок з'являється реальна можливість привернути до себе більше уваги і сприяти перетоку вільних грошових коштів на свої рахунки. Так само невигідно банкам залучати невеликі депозити на короткі терміни. У цьому сегменті також мають проявитися кредитні спілки, де, на відміну від банківських установ, і відсоткові ставки можуть бути вищими, а залучені вільні грошові кошти населення будуть спрямовані в кредитування і самого населення, і дрібного бізнесу фізичних осіб - суб'єктів підприємницької діяльності (Dmytrenko, 2003).

Висновки. Отже, можна зробити висновок, що відсутність достатнього фінансового забезпечення малих підприємницьких структур сфер послуг є головною причиною гальмування динамічного розвитку цього сектора вітчизняного підприємництва в умовах українського сьогодення. У сучасних умовах забезпечити фінансування інноваційних змін неможливо тільки через бюджетну систему або банківський сектор. Для створення цілісної системи, яка забезпечить належну підтримку розвитку діяльності малих та середніх підприємств сфери послуг та іiі інноваційну спрямованість необхідними коштами, потрібна "змішана" модель їх фінансування, яка включає державне сприяння розвитку спеціалізованих банківських кредитних установ, небанківських фінансових посередників (зокрема, інституційних інвесторів), альтернативну участь держави в методологічному та правовому забезпеченні.

На нашу думку, для того, щоб мале підприємництво сфер послуг ефективно функціонувало в українській економіці та давало позитивні інноваційні результати, оскільки воно це робить у провідних країнах світу, існує потреба посилити національну інноваційну систему та інфраструктуру в інтересах малих інноваційних підприємств, зокрема:

1. Реформувати саму структуру банківського сектора. Світовий досвід свідчить, що банківський сектор, що складається 3 двох ланок - центрального банку і комерційних банків, не в змозі забезпечити середньо- і довготермінового кредитування малих клієнтів. Для цього необхідно між цими двома рівнями побудувати певний буфер - банк другого рівня, спеціальну кредитну установу, яка за рахунок державних коштів здійснюватиме режим кредитування 3 метою сприяння розвитку, а не отримання комерційного прибутку.

2. Підвищити правову захищеність кредиторів та створити інституційну мотивацію залучення комерційних банків до кредитування малого підприємництва у сфері послуг для їх інноваційного розвитку.

3. Передбачити комплекс заходів 3 удосконалення відносин "банк-клієнт". 3 метою зменшення адміністративних та оперативних витрат комерційних банків необхідно запровадити режим пільгового оподаткування прибутку комерційних банків, що кредитують малий бізнес, зокрема, підприємства сфер послуг, та знизити нормативи обов'язкового резервування для банків, які здійснюють кредитування суб'єктів малого підприємництва.

4. Підтримання такого конструктивного фінансового інструменту, як фінансовий лізинг, який за своєю ефективністю рівносильний довготерміновому кредитуванню.

5. Сформувати уніфіковану державну політику підтримки небанківських фінансових установ та систему навчання фахівців кредитних спілок. Тому, окрім процедур і технологій, кредитним спілкам необхідні насамперед довготермінові й дешеві фінансові ресурси, для чого необхідно залучати їх до реалізації програм державного цільового мікрокредитування малого підприємництва, програм міжнародних фінансових організацій та програм НБУ в режимі рефінансування та цільових кредитів комерційних банків. Як метод у цьому питанні може дати ефект також створення при асоціаціях кредитних спілок фондів підтримки ліквідності.

6. Створення і розвиток ефективної франчайзингової мережі, оскільки відсутність знань та досвіду з цього питання, не дає змоги вітчизняним малим підприємцям правильно використовувати цей потужний інструмент інноваційного розвитку.

Реалізуючи невідкладні заходи 3 інноваційної політики сьогодні, ми інвестуємо в майбутнє України, формуємо національні конкурентні переваги і створюємо надійний фундамент для модернізації та інтеграції нашої країни до європейського і світового розвитку.

\section{Перелік використаних джерел}

Danylkiv, Kh. (2013). Kredytni spilky yak alternatyvne dzherelo dlia kredytuvannia maloho pidpryiemnytstva. Aktualni problemy funktsionuvannia hospodarskoi systemy Ukrainy: mater. KhKh Mizhnar. nauk. konferentsii studentiv, aspirantiv ta molodykh uchenykh, (pp. 67-68), 17-18 travnia 2013, m. Lviv, Ukraina. [In Ukrainian].

Danylkiv, Kh. P. (2012). Lizynhovi posluhy yak perspektyvna forma rozvytku malykh pidpryiemnytskykh struktur. Finansovo-ekonomichni problemy suchasnoho svitu: shliakhy i perspektyvy yikh vyrishennia na mikro-, makro- ta meha-rivniakh: mater. I-oi Vseukr. nauk.-prakt. konf. studentiv, aspirantiv $i$ molodykh vchenykh, (pp. 225-227), 24 liutoho 2012 r., m. Kremenchuk, Ukraina. Kremenchuk. [In Ukrainian].

Dmytrenko, M. A. (2003). Rol derzhavy u pidtrymtsi ta stymuliuvanni innovatsiinoi diialnosti. Visnyk Ukrainskoi akademii bankivskoi spravy, 1, 77-81. [In Ukrainian].

Dropa, Ya. B., \& Danylkiv, Kh. P. (2011). Osnovni dzherela finansovo-kredytnoho rozvytku maloho pidpryiemnytstva. Ekonomichnyi prostir, 52(2), 161-173. [In Ukrainian].

Kolodiziev, O. M. (2011). Finansove zabezpechennia innovatsiinoho rozvytku natsionalnoi ekonomiky. Doctoral Dissertation for Economic Sciences (08.00.08 - Money, Finance and Credit). DVNZ "Ukrainska akademiia bankivskoi spravy Natsionalnoho banku Ukrainy". Sumy. 508 p. [In Ukrainian].

Kychuk, O. S. (2009). Orhanyzatsyonno-jekonomycheskyi mekhanyzm sodeistvyia razvytyiu maloho predprynymatelstva. Candidate Dissertation for Economic Sciences (08.00.04 - Economy of management of property). Odessa. $226 \mathrm{p}$. [In Ukrainian].

Varnalii, Z. S. (2002). Franchaizynh yak efektyvna forma intehratsiinykh zviazkiv subiektiv maloho biznesu ta korporatsii. Aktualni problemy ekonomiky, 3, 47-53. [In Ukrainian].

Vozniak, H. V., \& Kuznietsova, A. Ya. (2007). Innovatsiina diialnist promyslovykh pidpryiemstv ta sposoby yii finansuvannia $v$ Ukraini: monohrafiia. Kyiv: UBS NBU. 183 p. [In Ukrainian]. 


\section{НЕКОТОРЫЕ ОСОБЕННОСТИ ФОРМИРОВАНИЯ ФИНАНСОВО-КРЕДИТНЫХ ИНСТРУМЕНТОВ ИННОВАЦИОННОГО РАЗВИТИЯ ПРЕДПРИЯТИЙ СФЕРЫ УСЛУГ}

Рассмотрены проблемы формирования в современных условиях инструментов инновационного развития предприятий сферы услуг. Исследованы предприятия сферы услуг (торговля, гостиницы, предприятия питания, туристические фирмы). Определены основные источники финансирования инновационного развития предприятий сферы услуг. Установлено, что финансовое обеспечение инновационного развития малых предпринимательских структур осуществляется в основном за счет собственных источников. Определены роль и значение финансово-кредитных инструментов для инновационного развития сферы услуг. Определены роль и место банковского кредитования в финансировании инновационного развития предприятий сферы услуг. Изучены место и значение использования лизинга как инструмента обеспечения инновационного развития малых предпринимательских структур. Рассмотрена роль франчайзинга и факторинга в обеспечении инновационного развития предпринимательских структур. Предложено создание эффективной франчайзинговой сети как средства финансирования инновационной деятельности малых предпринимательских структур. Рекомендовано украинским предпринимательским структурам в системе финансового обеспечения бизнес-деятельности использовать форфейтинг. Определено, что перспективным для финансирования инновационного развития предприятий сферы услуг является привлечение кредитных союзов и страховых компаний. Предложено реформировать структуру банковского сектора с целью создания банков второго уровня, которые бы осуществляли кредитование на льготных условиях. Предложенные рекомендации являются базовыми при формировании финансово-кредитного механизма инновационного развития предприятий сферы услуг.

Ключевые слова: самофинансирование; инвестиции; кредит; акционирование; лизинг; франчайзинг; кредитные союзы.

O. V. Major, N. A. Sveleba

Lviv Institute of Economy and Tourism, Lviv, Ukraine

\section{SOME FEATURES OF FORMATION OF FINANCIAL AND CREDIT INSTRUMENTS OF INNOVATIVE DEVELOPMENT OF SERVICE SECTOR ENTERPRISES}

The authors have considered the problems of formation of modern tools of innovative development of service sector enterprises. The enterprises of service sector including trade, hotels, catering enterprises, and travel companies are investigated. The main sources of financing of innovative development of service sector enterprises are determined. We have defined that financial support of innovative development of small business structures is carried out mainly due to owners' own sources. The role and significance of financial and credit instruments for innovation development of service sector are determined. The role and place of bank lending in the financing of innovative development of service enterprises are identified. The place and significance of the use of leasing as an instrument for providing innovative development of small business structures is studied. The role of franchising and factoring in providing innovative development of business structures is considered. The authors propose creating an effective franchising network as a means of financing innovative activities of small business entities. We suggest Ukrainian business entities to use forfeiting in the system of financial support of business activity. We have also determined that attraction of credit unions and insurance companies is promising for the financing of innovative development of service enterprises. It is proposed to reform the structure of the banking sector in order to create banks of the second level, which would lend on preferential terms. The proposed recommendations are the basis for the formation of the financial and credit mechanism of innovation development of service enterprises.

Keywords: self-financing; investments; credit; corporatization; leasing; franchising; credit unions. 